\title{
Informal Tools in Formal Contexts: Development of a Model to Assess the Acceptance of Mobile Technologies among Teachers
}

\author{
José Carlos Sánchez Prieto ${ }^{a}$ \\ josecarlos.sp@usal.es \\ Susana Olmos Migueláñez ${ }^{a}$ \\ solmos@usal.es \\ Francisco J. García-Peñalvo ${ }^{a}$ \\ fgarcia@usal.es \\ ${ }^{a}$ GRIAL Research Group, Research Institute for Educational Sciences, University of Salamanca, Spain.
}

\begin{abstract}
Traditionally, mobile learning has been more strongly developed within the field of informal education. However, in the past few years there has been a growing interest for the integration of these technologies in the formal education field. Among the key elements needed to successfully achieve this integration process is the acceptance of mobile technologies by the teaching body.

In this paper we propose to identify the determining constructs that explain the teachers' intention of using mobile technologies. To this end we have designed a research model based on the Technology Acceptance Model (TAM), expanded with constructs from other theories. The resulting model was subjected to a content validation process performed by a committee of experts.

Lastly, we selected nine constructs for the development of the research model and we formulated 13 hypotheses that describe the relationships among them. Further studies on the research model to extend its validity and reliability are suggested.

Keywords
\end{abstract}

mLearning; Technology Adoption; Technology Acceptance Model; In-service teachers; Attitude assessment.

\section{INTRODUCTION}

Over the past few years, mobile technologies have experienced an important expansion process and the consolidation of their popularity as devices used in day-to-day activities (Fundación Telefónica, 2014). This quick expansion has caused an increase in the fields that have shown interest in the advantages derived from the integration of these resources. Thus, the concept of mobile learning (mLearning) emerged in the educational field aiming to make the most out of mobile devices as learning tools.

This new methodology has been reinforced lately thanks to the incorporation of two devices, smartphones and tablets, which have strengthened the advantages inherent to mLearning, such as the individualization of the content, the increased flexibility of the learning process, the adaptability, the access to the information and the multimedia support, helping to overcome problems related with the autonomy or, in the case of the tablets, with content creation (Rossing, Miller, Cecil, \& Stamper, 2012). 
Sánchez Prieto, J. C., Olmos Migueláñez, S., \& García-Peñalvo, F. J. (2016). Informal Tools in Formal Contexts: Development of a Model to Assess the Acceptance of Mobile Technologies among Teachers. Computers in Human Behavior, 55A, 519-528.

Traditionally, mobile learning has been more strongly developed within the field of informal education, where we can find experiences in settings such as museums (Wishart \& Triggs, 2010). This phenomenon is mainly due to the fact that mLearning entails a more contextual, individualized and situated learning (Traxler, 2009).

The integration of processes and resources from informal education into formal education can contribute to offer educational solutions to help schools adapt to the needs of an ever-changing society that demands a more flexible and individualised education, and to locate the students at the centre of the teaching-learning process and offer them more control (Conde et al., 2012). As a consequence of this, there are a growing number of experiences on the use of mLearning as a bridge between informal and formal education (Dabbagh \& Kitsantas, 2012).

The educational application of these technologies promotes communication and the student's autonomous learning, and it allows us to take the teaching-learning process out of the classroom, thus enabling learning anytime, anywhere. This causes the barriers between formal and informal education to debilitate, demanding the development of new methodological strategies (Sharples, Amedillo Sanchez, Milrad, \& Vavoula, 2009) which contribute to opening up the schools to the outside world, creating bonds between schools and families and between teachers and students which allow teachers to guide the students learning process inside and outside the classroom (Mills, Knezek, \& Khaddage, 2014).

Currently, we can find experiences related to the integration of mobile devices in all stages of the formal education system, from the teaching of language and literature in pre-primary and primary education (Beschorner \& Hutchison, 2013; Hutchison, Beschorner, \& Schmidt-Crawford, 2012) to the creation of personal learning environments (PLE) (Conde González, García Peñalvo, Alier, \& Piguillem, 2013), including the use of tablets as an only working tool in zero-paper environments (Hesser \& Schwartz, 2013) or as a support for augmented reality (AR) applications in secondary education (Navarro, Galindo, \& Fonseca, 2013).

However, despite the growing interest, the integration of mLearning strategies in formal education institutions and processes is still at a primary development stage, given that the initiatives are isolated, they rarely have any continuity and in some cases they don't yield the expected results (Sánchez Prieto, Olmos Migueláñez, García Peñalvo, \& Torrecilla Sánchez, 2014).

One of the cornerstones of the integration of new technologies in the teaching-learning process is their acceptance by the teachers involved in said process (Chen, Looi, \& Chen, 2009). To this end, it is important to know the key elements that lead to technology acceptance so we can diagnose, predict and intervene in the appropriate situations.

With the objective of exploring and identifying the factors that determine primary teachers' acceptance of mobile technologies, we have proposed a model based on the Technology Acceptance Model (TAM) (Davis, 1989), which, based on the literature consulted, we have expanded by adding constructs and relational hypotheses from other models and theories such as Unified Theory of Acceptance and Use of Technology (UTAUT) (Venkatesh, Morris, Gordon B. Davis, \& Davis, 2003) or the Theory of Planned Bhaviour (TPB) (Ajzen, 1985). After drafting the original proposal, and aiming to ensure the validity of its content, a validation process was carried out by a group of experts from different fields.

In order to present said model, this paper will have the following structure: we will begin by describing the TAM model and its use as a tool to study technology acceptance processes in the educational field, then we will focus on presenting our model by explaining the foundation of the selected construct and describing the content 
Sánchez Prieto, J. C., Olmos Migueláñez, S., \& García-Peñalvo, F. J. (2016). Informal Tools in Formal Contexts: Development of a Model to Assess the Acceptance of Mobile Technologies among Teachers. Computers in Human Behavior, 55A, 519-528.

validation process, as well as the ensuing changes in the model. Lastly, we will present some brief conclusions where we will indicate the future steps in the process.

\section{THE TAM MODEL}

Since Davis (1986) formulated it, the TAM model has followed an intense evolution process over the years, until it became the reference model it is nowadays (Marangunié \& Granié, 2014).

In this section we will describe said process, from its direct antecedents to the current situation and the more frequent uses of the model in education.

\subsection{Origin and Evolution}

The main antecedent on the TAM model is the Theory of Reasoned Action (TRA) (Fishbein \& Ajzen, 1975). This theory, born within the field of social psychology, intends to predict a person's behavior through their behavioral intentions, understood as the subjective probability of an individual performing a given behavior, instead of their attitudes, which represent "A person's general feeling of favorableness or unfavorableness toward some stimulus object" (Ajzen, 1985, p. 156) and whose effect on behavior would be mediated by said behavioral intention.

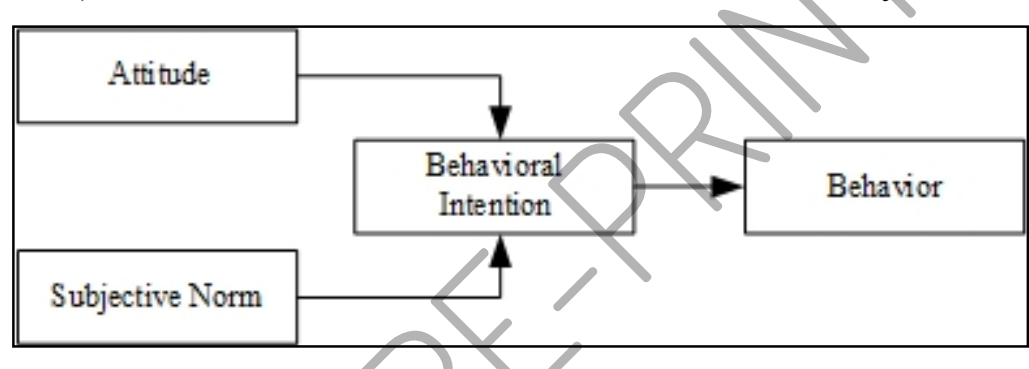

Figure 1. Theory of reasoned action (Fishbein \& Ajzen, 1975)

For Ajzen and Fishbein, behavioral intention is determined by the attitude towards the behavior and the subjective norm, which is the social or organisational pressure towards the performance of a behavior as perceived by an individual (Wu \& Chen, 2005).

Davis elaborated a simplified proposal from this theory's assumptions, adapted to analyse the information system (IS) adoption process, and maintaining the concept of behavioral intention (BI) as a direct antecedent of the behavior, which in this case is the actual use (AU) of a given information system.

Just like in the TRA, this behavioral intention would be determined by the individual's attitude, which would in its turn be conditioned by the usefulness and the ease of use of the information system as perceived by the individual.

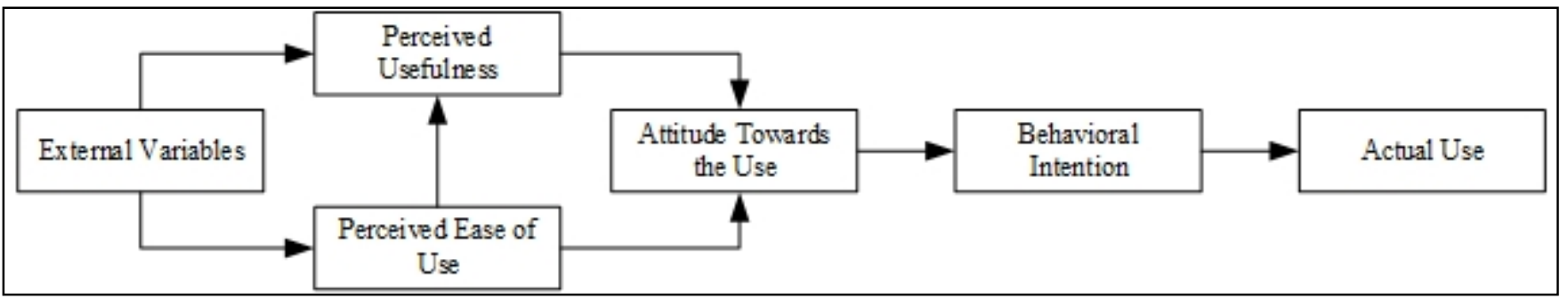

Figure 2. Technology acceptance model (Davis, 1989) 
Sánchez Prieto, J. C., Olmos Migueláñez, S., \& García-Peñalvo, F. J. (2016). Informal Tools in Formal Contexts: Development of a Model to Assess the Acceptance of Mobile Technologies among Teachers. Computers in Human Behavior, 55A, 519-528.

Davis defines perceived usefulness (PU) as, "the degree to which a person believes that using a particular system would enhance his or her job performance” (Davis, 1989, p.320)

On the other hand, perceived ease of use (PEU) is understood in this model as "the degree to which a person believes that using a particular system would be free from effort" (Davis, 1989, p.320). This construct would also influence the perceived usefulness, although there is some disagreement on this point among the scientific community (Hernández García, 2008).

The resultant proposal drafted by Davis has as its main advantage its simplicity and theoretical soundness, constituting a robust model which is able to explain a high percentage of the variance, which is why it is such an extended model (King \& He, 2006).

However, the TAM also presents a series of limitations, among which the following stand out (Hernández García, 2008; Legris, Ingham, \& Collerette, 2003):

- Lack of consideration of external variables: Including factors such as previous experience, perceived enjoyment or facilitating conditions.

- Dependence on self-reports: This dependence occurs when measuring the use of the system, which limits the reliability of the model and it hinders the study of the relationship between the BI and AU of the system (Agudo-Peregrina, Hernández-García, \& Pascual-Miguel, 2014).

- Low levels of variance in exploratory studies: In this type of studies, the explanation of behavioral intention can, on occasion, be relatively low.

Since its origin, and aiming to overcome these limitations, the model has evolved, sometimes including new constructs. Generally, the modifications made on the TAM can be grouped in the following categories (King \& He, 2006):

- Inclusion of external precursors: Such as previous experience and self-efficacy.

- Incorporation of factors suggested by other theories: Some authors add constructs from other theories aiming to increase the model's predictive ability.

- Inclusion of contextual factors: Factors from the environment of the organisation, the individual or the information system, such as: gender, culture, or the characteristics of the technology.

- Measurement of final elements: This group refers to the measurement of attitude, perceived use and actual use.

Aiming to incorporate the new findings derived from the expanded versions of the TAM, two new versions of the model have been proposed. The TAM2 (Venkatesh \& Davis, 2000), which incorporated factors such as subjective norm, previous experience or voluntariness, and the TAM3 (Venkatesh \& Bala, 2008), whose main feature is the proposal of anchor and adjustment factors that influence the perceived ease of use.

However, the complexity of the resulting models conflicts with the simplicity of the original proposal, reason why these two models are seldom used, in favour of extended versions of the TAM adapted to the context and IS in which they are intended to be applied

Currently, the TAM model is widely used to explain technology adoption processes (Lee, Cheung, \& Chen, 2005). It is most popular in fields such as commerce (Chen, Gillenson, \& Sherrell, 2002; Gefen, Karahanna, \& Straub, 2003; Wu \& Chen, 2005) or ICTs in organisations (Heijden, 2000; Hsu \& Lu, 2004; Yang, Cai, Zhou, \& Zhou, 2005), although we can also find examples of its use in the healthcare field (Hung \& Jen, 2012; Kuo, Liu, 
Sánchez Prieto, J. C., Olmos Migueláñez, S., \& García-Peñalvo, F. J. (2016). Informal Tools in Formal Contexts: Development of a Model to Assess the Acceptance of Mobile Technologies among Teachers. Computers in Human Behavior, 55A, 519-528.

\& Ma, 2013) and the educational field (Persico, Manca, \& Pozzi, 2014; Sánchez \& Hueros, 2010; Stantchev, Colomo-Palacios, Soto-Acosta, \& Misra, 2014).

\subsection{TAM And Education}

The variety of uses given to ICT within the educational field and the different roles and characteristics of its users make the study of technology acceptance a key element in the ICT integration process (Marangunié \& Granié, 2014).Below we present the most common educational applications of the TAM, sorted by their target population: students and teachers.

\subsubsection{TAM applied to students}

The two fields that concentrate a higher number of studies applying TAM to measure the students' technology acceptance are formal face-to-face education and eLearning.

Within the field of formal face-to-face education, we can find examples of the successful use of TAM to measure the acceptance of new technologies in high school students (Yu, Lin, Han, \& Hsu, 2012) or primary education pupils, such as the exploratory study carried out by (Deshpande, Bhattacharya, \& Yammiyavar, 2012).

However, the educational level most researched through TAM studies is university, where we find experiences that use Davis' original model to measure the acceptance of a given IS (Gao, 2005) or as a tool to measure the influence of external factors, such as motivation or academic success (Huffman \& Huffman, 2012; Jou \& Wang, 2012).

There are also studies focused on the students' acceptance of web tools as a complement to face-to-face education (Saadé \& Bahli, 2005), where, on occasion, the model is expanded by adding other constructs such as perceived enjoyment, self-efficacy or social influence (Chen, Lin, Yeh, \& Lou, 2013).

Within the field of eLearning we find research focused on studying its acceptance in higher education contexts, such as the research conducted by Ramayah (2010), who presents an expanded TAM model to study the effects of voluntariness, or the research carried out by Abbad, Morris and de Nahlik (2009), who present a TAM-based model that includes the constructs subjective norm, internet experience, system interactivity, self-efficacy and technical support.

We can also find a sizeable number of experiences in continuous education environments to study the role of gender in technological acceptance (Ong \& Lai, 2006) or the effect of complexity (Lee, Hsieh, \& Hsu, 2011).

Lastly, there are studies on the students' technology acceptance focused mostly on the university level (Yadegaridehkordi, Iahad, \& Baloch, 2013; Yamakawa, Delgado, Díaz, Garayar, \& Laguna, 2013)

\subsubsection{TAM applied to teachers}

There are also studies focused on the acceptance of ICTs among teachers. Below, we present the most relevant ones, both with pre-service and in-service teachers.

The TAM model can be useful in order to evaluate the acceptance of an IS among pre-service teachers and to try to estimate the probability of such system to be accepted among the teachers in the future (King \& He, 2006), although this data are not always translatable (Legris et al., 2003).

On this context we find investigations that use the TAM without modifications (Koutromanos, Styliaras, \& Christodoulou, 2014), both to measure the acceptance of a certain technology or to predict the effects of constructs that are external to the model, such as the research carried out by Kiraz and Ozdemir (2006) on the effects of ideology on acceptance. 
Sánchez Prieto, J. C., Olmos Migueláñez, S., \& García-Peñalvo, F. J. (2016). Informal Tools in Formal Contexts: Development of a Model to Assess the Acceptance of Mobile Technologies among Teachers. Computers in Human Behavior, 55A, 519-528.

The research of the factors that lead to the technological adoption among the teachers is becoming more important due to the fundamental role that they play in the process of technology integration (Liaw, Huang, \& Chen, 2007).

Thus, there are investigations that use the TAM with primary education teachers, like the one carried out by Wu and Liu (2013) to examine the effect of the cognitive styles using a model that also integrated elements from the Innovation Diffusion Theory (IDT) (Rogers, 1995). In the context of higher education, Park, Lee and Cheong (2007) also applied an extended TAM model to study the acceptance of a courseware.

Lastly, it is worth mentioning the research conducted by Pynoo y Braak (2014), on the acceptance of an educational portal aimed at teachers of all levels. This study focused on the relationship between BI and AU, the latter divided in generative use and receptive use. The study concluded that there was a relationship between BI and receptive use, but not between BI and generative use, which begged to delve into the study of this relationship, which is key to technology acceptance models.

\section{AN EXTENDED TAM MODEL TO MEASURE MOBILE ACCEPTANCE}

In this section we will present the drafting process of our model. We will begin with the original proposal and the content validation process it was subjected to, and then we will describe the final model, defining the selected constructs and their relational hypotheses.

\subsection{Original Proposal And Validation Process}

Our model takes Davis' original proposal as a starting point, maintaining the concepts of perceived usefulness, perceived ease of use and behavioral intention. The concept of attitude towards use was eliminated from the model, mainly due to its limited moderating effect (Hu, Clark, \& Ma, 2003), with the aim of simplifying the model and reducing the number of items on the instrument to facilitate participation. Therefore we linked PEU and PU directly with BI along the lines of other models such as TAM2 or TAM3, which constitutes an extended practice in the design of TAM based models (Abbad et al., 2009; Park et al., 2007; Roca \& Gagné, 2008a; Saadé \& Bahli, 2005)

The proposed model has been designed with the objective of conducting a study on the acceptance of mobile technologies among the primary education teachers of the Autonomous Community of Castile and Leon (Spain). Due to the heterogeneity of technology resources available at schools and the dispersion of the schools in said region, we deemed it inadequate to conduct a study that considered the actual use of technologies that, in some cases, might not be available to teachers, and thus we decided to remove the construct AU and focus our model on other studies based on the TAM model that were also carried out in educational settings (Abbad et al., 2009; Chen et al., 2013; Roca \& Gagné, 2008b; Saadé \& Bahli, 2005; C. Wu \& Liu, 2013).

The use of technology acceptance models that propose the BI as the dependent variable of studies with teachers presents several advantages. On the one hand, as we have mentioned before, it solves the problem of the application of the model in contexts where these technologies are not available (Bourgonjon et al., 2013). Another important advantage is that the information on the actual use of a given technology might be considered too sensitive by schools, and that might hinder participation. Lastly, the use of self-reports to register the actual use of the technology makes the teachers' answers less reliable (Teo, 2011). Bearing this in mind, the selection of the BI as the dependant variable seemed the most reasonable option from a pragmatic point of view (Hu et al., 2003). This alternative is frequently employed in acceptance models designed for studies with teachers (Adiguzel, Capraro, \& Willson, 2011; Chen \& Tseng, 2012; Teo, 2009; Teo \& Noyes, 2011). 
Sánchez Prieto, J. C., Olmos Migueláñez, S., \& García-Peñalvo, F. J. (2016). Informal Tools in Formal Contexts: Development of a Model to Assess the Acceptance of Mobile Technologies among Teachers. Computers in Human Behavior, 55A, 519-528.

After conducting a literature review we deemed it necessary to complete the model with exogenous and endogenous variables which would help explain the variance. Thus we selected the following variables from other models such as TRA, TPB, UTAUT, TAM2 or TAM3: previous experience (PE), perceived enjoyment (PEN), subjective norm (SN), self-efficacy (SE) and facilitating conditions (FC). The table below shows the most relevant articles we consulted regarding the selected constructs.

\begin{tabular}{|c|c|c|c|c|c|c|c|c|}
\hline & $\mathrm{PU}$ & PEU & BI & $\mathrm{PE}$ & PEN & SN & SE & $\mathrm{FC}$ \\
\hline (Venkatesh \& Davis, 2000) & - & - & - & - & & - & & \\
\hline (Venkatesh \& Bala, 2008) & - & - & - & - & - & - & - & \\
\hline (Venkatesh et al., 2003) & & & - & - & & & & - \\
\hline Bourgonjon et al., 2013 & - & & - & - & & - & & \\
\hline$(\mathrm{Gao}, 2005)$ & - & - & - & & & & & \\
\hline (Hu et al., 2003) & - & - & & & & - & - & \\
\hline (Davis, Bagozzi, \& Warshaw, 1992) & & & & & - & & & \\
\hline (Bandura, 1978) & & & & & & & - & \\
\hline (Compeau \& Higgins, 1995) & & & se & & & & - & \\
\hline (Schepers \& Wetzels, 2007) & e & - & - & & & - & & \\
\hline$($ Teo, 2010) & & - & - & & & - & & - \\
\hline Teo \& Noyes, 2011 & & - & - & & - & & & - \\
\hline (Echeng, Usoro, \& Majewski, 2013) & - & - & - & & & & & - \\
\hline Lee, Cheung, \& Chen, 2005 & - & - & - & & - & & & \\
\hline $\begin{array}{l}\text { (De Smet, Bourgonjon, De Wever, } \\
\text { Schellens, \& Valcke, 2012) }\end{array}$ & - & - & - & - & & - & & \\
\hline
\end{tabular}

Table 1. Relevant studies consulted

Once we selected the constructs, and on the basis of the consulted literature, we formulated the relational hypotheses (Fig. 3). 
Sánchez Prieto, J. C., Olmos Migueláñez, S., \& García-Peñalvo, F. J. (2016). Informal Tools in Formal Contexts: Development of a Model to Assess the Acceptance of Mobile Technologies among Teachers. Computers in Human Behavior, 55A, 519-528.

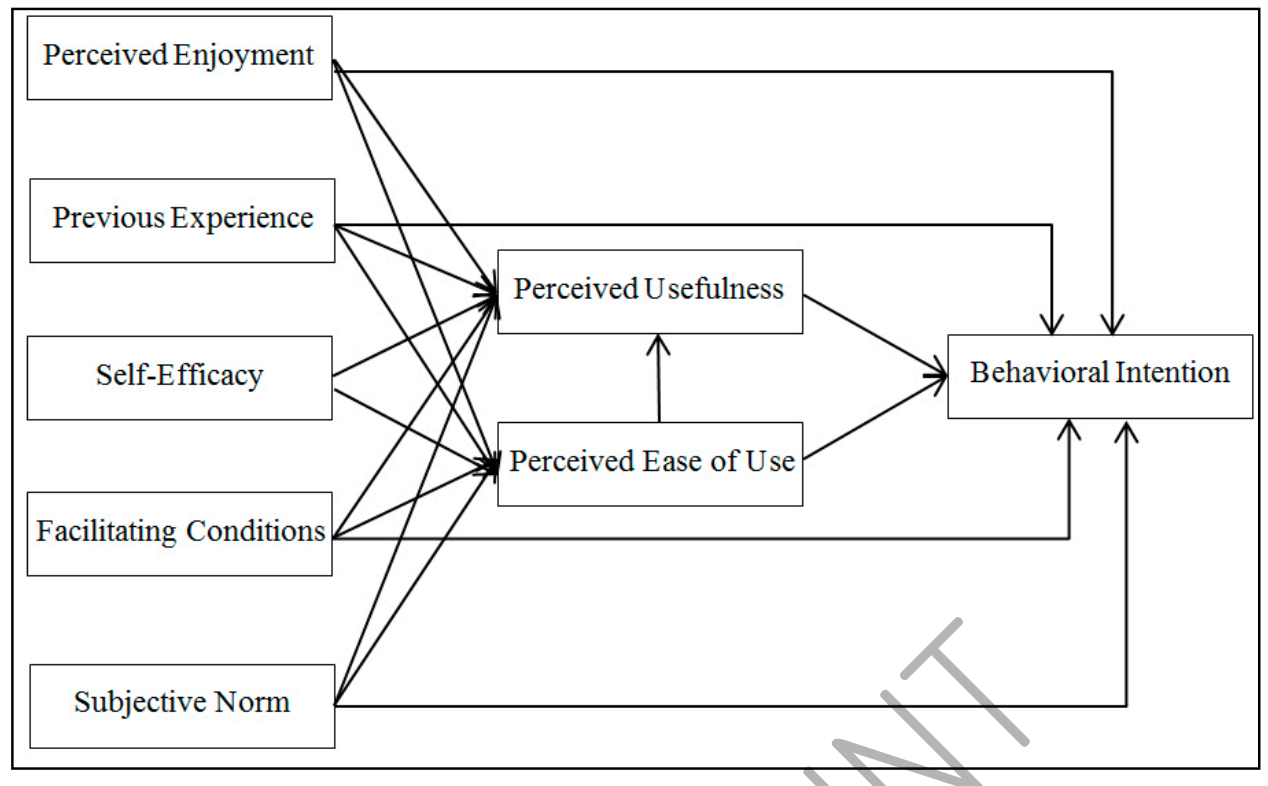

Figure 3. Original proposal of the Extended TAM Model.

After the constructs and their relationships were selected and defined, we designed the instrument to carry out the data gathering. The instrument is divided in two sections. The first one is designed to gather the participants' identification data, including: age, gender, type of school and years of teaching experience.

The second part of the instrument is made up of a set of items formulated in a Likert-type scale of seven intervals ranged from 0 to 6 (0: Completely disagree; 1: Disagree; 2: Somewhat disagree; 3: Neither agree nor disagree; 4: Somewhat agree; 5: Agree; 6: Completely agree). We decided to start our scale from zero so as to better reflect the notion of total disagreement. A scale with an odd number of intervals was chosen in order to obtain more answers on account of the scale having a middle value, deciding on seven intervals to achieve a higher degree of reliability (Morales Vallejo, Urosa Sanz \& Blanco Blanco, 2003).

We drew up a total of 64 items (table 1), 8 of which, corresponding to the perceived ease of use and the perceived usefulness, were directly adapted from Davis' original proposal. We performed a selection of the rest of the items after the content validation process.

\begin{tabular}{|l|c|}
\hline Construct & Number of Items \\
\hline Perceived Usefulness & 4 \\
\hline Perceived Ease of Use & 4 \\
\hline Behavioral Intention & 6 \\
\hline Previous Experience & 10 \\
\hline Perceived enjoyment & 10 \\
\hline Self-efficacy & 10 \\
\hline Facilitating Conditions & 10 \\
\hline Subjective Norm & 10 \\
\hline
\end{tabular}

Table 2. Distribution of the number of items per construct

\footnotetext{
${ }^{1}$ The complete list of items can be consulted in the following link: https://goo.gl/LAV06Z
} 
Sánchez Prieto, J. C., Olmos Migueláñez, S., \& García-Peñalvo, F. J. (2016). Informal Tools in Formal Contexts: Development of a Model to Assess the Acceptance of Mobile Technologies among Teachers. Computers in Human Behavior, 55A, 519-528.

\subsubsection{Content Validation Process}

To conduct the content validation process we drafted a validation tool, which was adapted from the proposal by Martínez Abad (2013). This tool contains a brief introduction on the TAM model and a description of our theoretical model, and it lays out the evaluation process in three stages.

The first stage was intended for the independent assessment of each item. For this, we presented the questions for gathering the teachers' identification data as well as the set of proposed items grouped by construct for the experts to assess them (on a scale from 0 to 6), based on three criteria: pertinence, defined as the correspondence between the content of the item and the construct it belongs to; clarity, which refers to the precision and understandability of the item; and relevance, understood as the degree of importance of the item in the explanation of the dimension.

At the end of each group of items we included a section to gather comments, suggestions and alternative ways to word the items.

In the second stage, the evaluators had to analyse the quality of each construct, by assessing the degree to which the proposed items as a whole contributed to evaluating the construct at a global level. We designed the following criteria for each construct: validity of the dimension (on a scale of 0 to 6) to measure the degree to which the items of the dimension as a whole explain the dimension they belong to; strengths and weaknesses of the dimension, expressed in a qualitative way; and an obseryations section aimed at collecting comments on the dimension.

Lastly, in the third stage we asked the evaluators to cast judgement on the global ability of the instrument to assess the primary education teachers' acceptance of mobile technologies according to its adequacy. We proposed the following criteria to assess (on a scale of 0 to 6): Global validity of the tool, measured according to the ability of the dimensions as a whole to explain the acceptance of mobile technologies; adequacy, defined as the degree to which the proposed instrument adjusts to the assessment of the acceptance of mobile technologies; relevance of the dimensions, which designates the degree to which each dimension collaborates in the explanation of the process of acceptance of mobile technologies.

Moreover on this stage, we included two sections for gathering qualitative information: one for the instrument's strengths and weaknesses, and the other for general observations.

After drafting the instrument, we selected a group of six external evaluators, made up by researchers from different educational and computer science fields, from national and international universities. We contacted this group to ask for their collaboration and we provided the instrument either by e-mail or in person.

Once we received the assessments, we converted them to a digital format to facilitate the result evaluation process. According to the results, we proceeded with the selection of items and constructs.

We deleted the items-factors with average values under three, performed in-depth modifications on the items with values between three and five and modifications in the formulation of the items-factors with values over five. Finally we also took in consideration the experts' qualitative suggestions which were pertinent for the studied theoretical framework. After this we chose those which had obtained the highest scores.

Regarding the individual item assessment carried out in the first stage, we obtained overall positive scores. Table 2 shows the average and standard deviation of the set of items that make up each construct, according to the three criteria established. Out of the six participating judges, four completed the quantitative part of this phase, with the two remaining judges opting to offer only their qualitative opinion through the comment section. 
Sánchez Prieto, J. C., Olmos Migueláñez, S., \& García-Peñalvo, F. J. (2016). Informal Tools in Formal Contexts: Development of a Model to Assess the Acceptance of Mobile Technologies among Teachers. Computers in Human Behavior, 55A, 519-528.

\begin{tabular}{|l|l|l|l|l|l|l|l|l|l|}
\hline & \multicolumn{3}{|l|}{ Pertinence } & \multicolumn{4}{l|}{ Relevance } & \multicolumn{3}{l|}{ Clarity } \\
\cline { 2 - 11 } & AVG & STD & N & AVG & STD & N & AVG & STD & N \\
\hline PU & 5,67 &, 651 & 12 & 5,42 &, 900 & 12 & 5,42 &, 793 & 12 \\
\hline PEU & 4,67 & 1,670 & 12 & 4,75 & 1,545 & 12 & 4,92 & 1,505 & 12 \\
\hline BI & 4,83 &, 924 & 18 & 4,72 & 1,364 & 18 & 5,44 &, 511 & 18 \\
\hline PE & 4,83 & 1,464 & 30 & 5,00 & 1,313 & 30 & 4,57 & 1,331 & 30 \\
\hline PEN & 5,37 &, 964 & 30 & 5,27 &, 907 & 30 & 5,37 &, 809 & 30 \\
\hline SE & 5,33 & 1,028 & 30 & 5,33 & 1,061 & 30 & 4,97 & 1,299 & 30 \\
\hline FC & 5,46 & 1,120 & 37 & 5,68 &, 884 & 37 & 5,11 & 1,350 & 37 \\
\hline SN & 5,03 & 1,797 & 36 & 5,27 & 1,644 & 37 & 4,81 & 1,808 & 37 \\
\hline
\end{tabular}

Table 3. Descriptives of items in Phase 1, grouped by construct.

Most of the suggestions were related to an improvement of the clarity of the formulation and the reduction of the number of items per construct to avoid redundancies. Since reducing the number of items to those that obtained the higher scores was the initial objective of this process, this suggestion was not seen as negative. The comments were generally related to alternative formulations for the items and bibliographic recommendations which were taken into account for the drafting of the final model.

As for the assessments of the dimensions in the second stage, and the instrument's global validity of the third stage, these turned out to be positive as well, with average scores ranging between 4 and 6 , and an average global validity of 5 (Table 4). Of the six judges, five completed the qualitative part of the phases 2 and 3 , with the remaining judge offering his opinion in a qualitative way.

\begin{tabular}{|c|c|c|c|}
\hline 1 & $\mathrm{AVG}$ & STD & $\mathrm{N}$ \\
\hline PU & 5,40 & ,894 & 5 \\
\hline PEU & 5,20 & 1,095 & 5 \\
\hline BI & 5,20 & 1,095 & 5 \\
\hline PE & 5,00 & 1,225 & 5 \\
\hline PEN & 4,40 & 1,342 & 5 \\
\hline SE & 5,00 & 1,732 & 5 \\
\hline $\mathrm{FC}$ & 5,20 & ,837 & 5 \\
\hline SN & 5,40 & ,894 & 5 \\
\hline $\mathrm{GV}$ & 5 & 1 & 5 \\
\hline
\end{tabular}

Table 4. Descriptives of dimensions in Phase 2 and Global Validity (GV)

The evaluators pointed out the theoretical basis of the instrument as one of its strengths, and the excessive amount of items per construct and the risk of multicollineality due to their similarities as the weak points of the instrument. 
Sánchez Prieto, J. C., Olmos Migueláñez, S., \& García-Peñalvo, F. J. (2016). Informal Tools in Formal Contexts: Development of a Model to Assess the Acceptance of Mobile Technologies among Teachers. Computers in Human Behavior, 55A, 519-528.

We were also suggested to reduce the number of relational hypotheses, to include less used constructs, such as the resistance to change, and to reconsider the construct previous experience as a moderating variable.

\subsection{Description of the Model}

Taking into account the experts' suggestions, we drafted the final model including the following construct to expand the TAM: perceived enjoyment, subjective norm, self-efficacy, facilitating conditions, anxiety towards mobile devices and resistance to change. All the selected constructs are understood as formative constructs.

Previous experience, which was included in the original proposal defined as the individual's previous experience with mobile devices on a day-to-day basis, was included as a moderating variable. The rest of the moderating variables selected where: age, expressed as a continuous variable; gender, formulated as a dichotomous nominal variable; years of teaching experience, expressed as a continuous variable; and type of school, formulated as a nominal variable divided in three categories representing the three types of schools where primary education can be imparted in Spain: CEIP (Public Pre-primary and Primary Education Schools), CRA (Grouped Rural Schools) and CEO (Compulsory Education Schools).

The originally proposed Likert-type scale of seven intervals which ranged from 0 to 6 was modified following the suggestions of some of the judges, who recommended turning it into a scale ranging from 1 to 7 (1: Completely disagree; 2: Disagree; 3: Somewhat disagree; 4: Neither agree nor disagree; 5: Somewhat agree; 6: Agree; 7: Completely agree), which is more frequently used.

Lastly, we also modified the relational hypotheses by reducing their number to avoid interferences during the analysis (Fig. 4).

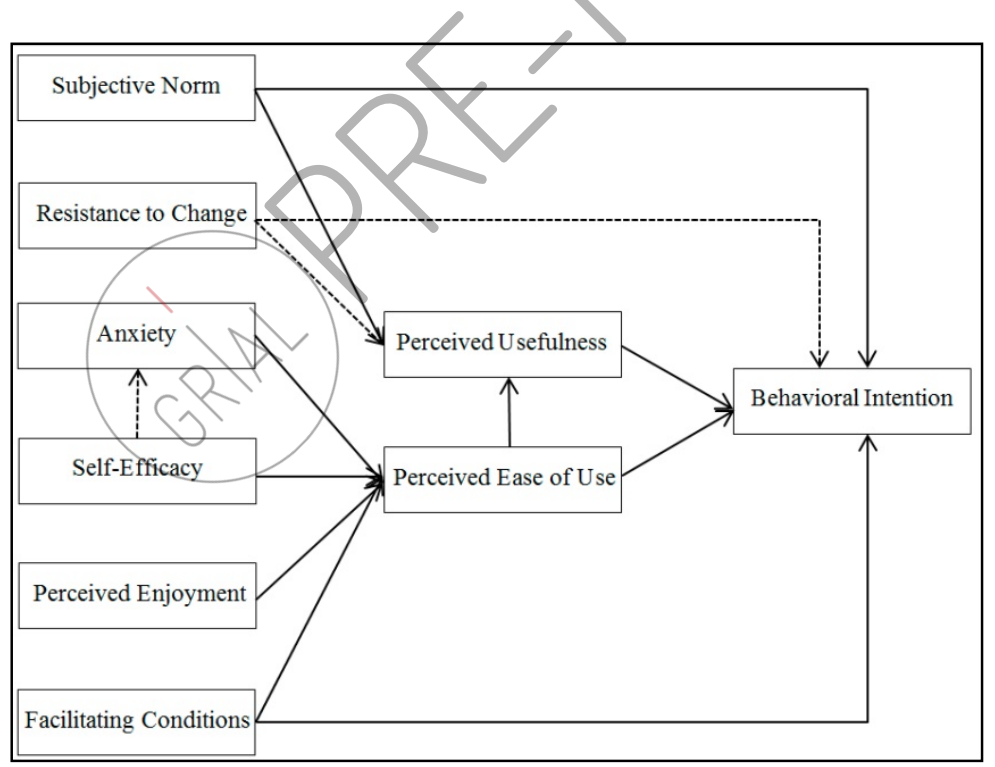

Figure 4. Extended TAM

We selected a total of 26 items for the constructs that were incorporated in the final model, which are included in the following table:

\begin{tabular}{|l|l|}
\hline \multicolumn{2}{|l|}{ Perceived Usefulness } \\
\hline PU1 & The use of mobile technologies can enhance my job performance. \\
\hline PU2 & The use of mobile technologies can make me more effective at work. \\
\hline
\end{tabular}


Sánchez Prieto, J. C., Olmos Migueláñez, S., \& García-Peñalvo, F. J. (2016). Informal Tools in Formal Contexts: Development of a Model to Assess the Acceptance of Mobile Technologies among Teachers. Computers in Human Behavior, 55A, 519-528.

\begin{tabular}{|c|c|}
\hline PU3 & The use of mobile devices in my teaching practice enhances my productivity. \\
\hline PU4 & Generally I consider that mobile devices can be useful in my line of work. \\
\hline \multicolumn{2}{|c|}{ Perceived Ease of Use } \\
\hline PEU1 & Learning to use mobile devices in the classroom would be easy for me. \\
\hline PEU2 & I find it easy to interact with mobile devices. \\
\hline PEU3 & Interaction with mobile devices is clear and easy to understand for me. \\
\hline PEU4 & Generally I consider that mobile devices are easy to use. \\
\hline \multicolumn{2}{|c|}{ Behavioral Intention } \\
\hline BI1 & I intend to use mobile devices in the classroom. \\
\hline $\mathrm{BI} 2$ & I predict I will use mobile technologies at my job. \\
\hline $\mathrm{BI} 3$ & I plan to use mobile devices in the implementation of my teaching practice. \\
\hline \multicolumn{2}{|c|}{ Self-efficacy } \\
\hline SE1 & I am able to integrate mobile devices in my teaching practice. \\
\hline SE2 & I can use mobile devices as educational tools even if there is no one to help me. \\
\hline SE3 & I can design materials and activities for mobile devices without external help. \\
\hline \multicolumn{2}{|r|}{ Facilitating Conditions } \\
\hline FC1 & I have enough time to include mobile devices in my teaching practice. \\
\hline FC2 & I have easy access to the materials I need to develop educational activities delivered through mobile devices. \\
\hline FC3 & I have the necessary human resources at my disposal to be able to develop educational activities with mobile devices. \\
\hline \multicolumn{2}{|r|}{ Subjective Norm } \\
\hline SN1 & My coworkers think I should use mobile technologies in my classroom. \\
\hline SN2 & In my school, teachers are expected to use mobile devices in the classroom. \\
\hline SN3 & The people who influence my behaviour think I should use mobile devices in the classroom. \\
\hline \multicolumn{2}{|r|}{ Mobile Device Anxiety } \\
\hline MA1 & I doubt about using mobile technologies in the classroom because I fear making mistakes that I can't correct. \\
\hline MA2 & Generally the use of mobile devices in the classroom stresses me out. \\
\hline MA3 & I feel apprehension towards the use of mobile devices. \\
\hline \multicolumn{2}{|c|}{ Resistance to Change } \\
\hline $\mathrm{RC} 1$ & I would like mobile technologies to change the way the teaching practice is implemented. \\
\hline $\mathrm{RC} 2$ & I want mobile technologies to change teacher-student interactions. \\
\hline RC3 & I would find it easy to assume changes in the teaching methodology introduced my mobile devices. \\
\hline
\end{tabular}

\section{Table 5. Items for the extended TAM model}

Below, we will perform a comprehensive analysis of the selected constructs and the relational hypotheses.

\subsubsection{Perceived usefulness, Perceived ease of use and Behavioral intention}

As we have mentioned before, the constructs of perceived usefulness, perceived ease of use and behavioral intention come from the TAM model. For the drafting of our model, the items belonging to perceived usefulness and perceived ease of use have been formulated using Davis' proposal (1989), and the items for behavioral intention were formulated using the TAM3. 
Sánchez Prieto, J. C., Olmos Migueláñez, S., \& García-Peñalvo, F. J. (2016). Informal Tools in Formal Contexts: Development of a Model to Assess the Acceptance of Mobile Technologies among Teachers. Computers in Human Behavior, 55A, 519-528.

The hypotheses for these constructs are as follows:

H1: Perceived usefulness has a positive relation with primary teachers' behavioral intention to use mobile devices.

H2: Perceived ease of use has a positive relation with primary teachers' behavioral intention to use mobile devices

H3: Perceived ease of use has a positive relation with primary teachers' perceived usefulness.

\subsubsection{Perceived enjoyment}

This construct comes from the motivational technology acceptance model (MM) (Davis et al., 1992), which explores the intrinsic factors that lead an individual to accept an IS. It is defined as the degree to which the use of the technology is perceived as enjoyable, regardless of the performance consequences that can be anticipated.

The use of this construct is rather extended, both to expand the TAM model and to be integrated in other models such as the TAM3. Its use has yielded good results with teachers, in research such as that conducted by Al-Debei (2014) and Teo and Noyes (2011).

The hypothesis for this construct in our model is:

H4: Perceived enjoyment has a positive relation with primary teachers' perceived ease of use.

\subsubsection{Subjective norm}

Subjective norm is a construct formulated within the TRA, and it plays an important role in the TPB (Ajzen, 1985 ) to describe the organisational or social pressure placed on the individual to perform a given behavior, as perceived by said individual. In our model it represents the social pressure placed on teachers to use a given technology. This variable appears frequently in other research (Teo, 2012b; Yuen \& Ma, 2008). To formulate the items for this construct we considered the proposals by Venkatesh and Davis (2000) and Venkatesh and Bala (2008), including the following hypotheses:

H5: Subjective norm has a positive relation with primary teachers' perceived usefulness.

H6: Subjective norm has a positive relation with primary teachers' behavioral intention to use mobile devices.

\subsubsection{Self-efficacy}

It is described as the assessment made by an individual on their ability to properly use the devices. This term, proposed by Bandura, comes from the social cognitive theory (1978), and we can find examples of its use with positive results in a sizeable number of studies (Chen \& Tseng, 2012; Holden \& Rada, 2011; van Dinther, Dochy, Segers, \& Braeken, 2013; Yuen \& Ma, 2008). In our model, we include the following hypotheses based on the TAM3 model:

H7: Primary teachers' self-efficacy has a positive relation with their perceived ease of use.

H8: Primary teachers' self-efficacy has a negative relation with their mobile device anxiety.

\subsubsection{Mobile device anxiety}

This construct was not included in the original proposal and was added to the model because it is strongly linked to self-efficacy. It is an adaptation to the construct of computer anxiety from the TAM3 model. This construct is defined as the degree of an individual's apprehension, or even fear, when he/she is faced with the possibility of using mobile technologies (Hernández García, 2008). For this construct we propose the following hypothesis:

H9: Primary teachers' mobile device anxiety has a negative relation with their perceived ease of use. 
Sánchez Prieto, J. C., Olmos Migueláñez, S., \& García-Peñalvo, F. J. (2016). Informal Tools in Formal Contexts: Development of a Model to Assess the Acceptance of Mobile Technologies among Teachers. Computers in Human Behavior, 55A, 519-528.

\subsubsection{Facilitating conditions}

This construct measures the individual's perception of the resources at their disposal to support their behavior. This concept is integrated in the unified theory of acceptance and use of technology (UTAUT) (Venkatesh et al., 2003) and it has yielded good results in previous studies on teachers' and students' technology acceptance (Deshpande et al., 2012; Echeng et al., 2013; Teo, 2011). Our model includes the following hypotheses:

H10: Facilitating conditions have a positive relation with primary teachers' perceived ease of use.

H11: Facilitating conditions have a positive relation with primary teachers' behavioral intention to use mobile devices.

\subsubsection{Resistance to change}

Resistance to change can be defined as the difficulty to break with routines and the emotional stress generated when facing the expectation of changes. Although it is not included in any of the main theories, it has been explored in acceptance studies based on TAM (Al-Somali, Gholami, \& Clegg, 2009).

During the validation process, we were told that including this construct in the model could be interesting and, after a bibliographic analysis we decided to add it as a variable because, although it is a relatively unexplored construct, we considered it might have a significant influence on the acceptance of mobile technologies by primary teachers, bearing in mind the stress that the changes demanded by the integration of ICTs produce in this professional collective (Al-Fudail \& Mellar, 2008).

This definition of the construct is closely linked to perceived compatibility (Escobar-Rodríguez \& BartualSopena, 2014), which comes from the IDT and it is described as the extent to which an innovation is perceived to be consistent with the individual's existing values, previous experiences and needs (Rogers, 1995). This way, resistance to change would be close to the constructs of Compatibility with Preferred Work Style and Compatibility with Existing Practices proposed by Karahanna, Agarwal and Angst (2006).

The items for this construct were adapted from the proposals for resistance to change by Bhattacherjee and Hikmet (2007) and Guo, Sun, Wang, Pemg and Yan (2013), who propose to formulate the items in an inverse way.

Our model proposes the following relational hypotheses for resistance to change:

H12: Resistance to change has a negative relation with primary teachers' perceived usefulness.

H13: Resistance to change has a negative relation with primary teachers' behavioral intention to use mobile devices.

\section{CONCLUSIONS}

The use of educational strategies that employ mobile devices within the formal teaching-learning process allows us to blur the limits between formal and informal education, which places mobile learning as a bridge between both fields and it opens the door to new didactic strategies and designs which will facilitate to take the educational process out of the classroom, broadening the range of solutions to the problems of teachers and students.

In every technology integration process, the involvement of teachers has a central role, and therefore the knowledge on the teachers' attitudes towards mobile technologies is a key element to successfully guide the process of incorporating these devices to the teaching practice (Hernández-Ramos, Martínez-Abad, García Peñalvo, Esperanza Herrera García, \& Rodríguez-Conde, 2014). 
Sánchez Prieto, J. C., Olmos Migueláñez, S., \& García-Peñalvo, F. J. (2016). Informal Tools in Formal Contexts: Development of a Model to Assess the Acceptance of Mobile Technologies among Teachers. Computers in Human Behavior, 55A, 519-528.

Although there are studies that explore the process of technology acceptance among teachers, and their number is increasing, along with the growing interest for the integration of new technologies in the classroom (Marangunié \& Granié, 2014), we do not yet have a complex model that explains the relationships among the different factors and how they influence the behavioral intention (Teo, 2012a), having found that a significant number of studies are focused on exploring the effects derived from adding a construct to the TAM model and its interaction with the rest of the model's constructs.

Our proposal consists in a new model specifically designed to explain the teachers' acceptance of mobile technologies. The proposal is drafted from the TAM model, and expanded with constructs from other models such as TRA, TPB, UTAUT, IDT or TAM3.

The result is a complete theoretical model that integrates the constructs considered the most relevant to explain the process: perceived enjoyment, facilitating conditions, self-efficacy, mobile device anxiety, subjective norm, perceived usefulness, perceived ease of use and behavioral intention. It also includes a construct that has been relatively unexplored in previous studies, such as the resistance to change, which has shown interesting results in studies like the one carried out by Bhattacherjee and Hikmet (2007) to study the acceptance of healthcare technologies by physicians, or the research by Guo, Sun, Wang, Peng and Yan (2013) to measure the acceptance of mobile technologies among elders in the healthcare context. Despite these results, we haven't found any research on its effect on teachers' technological acceptance.

These variables have been grouped and defined for their assessment and the determination of their level of statistical significance, explaining the relationship among them via the formulation of 13 relational hypotheses and 26 items to conduct the data gathering process to perform the research, allowing the replication of the study and the expansion and modification of the model. This model and its corresponding instrument have been subjected to an assessment process performed by a group of experts in order to ensure the validity of its contents.

The present research opens the door to further investigations, including the replication of the study through a statistical validation process in order to ensure and extend the reliability and validity of the proposal, or the undertaking of researches to delve into the less used constructs, such as self-efficacy or mobile anxiety, and especially into the construct of resistance to change and its relationship with perceived compatibility.

\section{REFERENCES}

Abbad, M. M., Morris, D., \& de Nahlik, C. (2009). Looking under the bonnet: Factors affecting student adoption of E-learning systems in jordan. International Review of Research in Open and Distance Learning, 10(2)

Adiguzel, T., Capraro, R. M., \& Willson, V. L. (2011). An examination of teacher acceptance of handheld computers. International Journal of Special Education, 26(3), 12-27.

Agudo-Peregrina, Á F., Hernández-García, Á, \& Pascual-Miguel, F. J. (2014). Behavioral intention, use behavior and the acceptance of electronic learning systems: Differences between higher education and lifelong learning. Computers in Human Behavior, 34(0), 301-314. doi:http://dx.doi.org/10.1016/j.chb.2013.10.035

Ajzen, I. (1985). From intentions to actions: A theory of planned behavior. In J. Kuhl, \& J. Beckmann (Eds.), (pp. 11-39) Springer Berlin Heidelberg. doi:10.1007/978-3-642-69746-3 2

Al-Debei, M. M. (2014). The quality and acceptance of websites: An empirical investigation in the context of higher education. International Journal of Business Information Systems, 15(2), 170-188.

Al-Fudail, M., \& Mellar, H. (2008). Investigating teacher stress when using technology. Computers \& Education, 51(3), 1103-1110. doi:http://dx.doi.org/10.1016/j.compedu.2007.11.004 
Sánchez Prieto, J. C., Olmos Migueláñez, S., \& García-Peñalvo, F. J. (2016). Informal Tools in Formal Contexts: Development of a Model to Assess the Acceptance of Mobile Technologies among Teachers. Computers in Human Behavior, 55A, 519-528.

Al-Somali, S. A., Gholami, R., \& Clegg, B. (2009). An investigation into the acceptance of online banking in saudi arabia. Technovation, 29(2), 130-141.

Bandura, A. (1978). Self-efficacy: Toward a unifying theory of behavior change. Psychological Review, (84), 191-215.

Beschorner, B., \& Hutchison, A. (2013). iPads as a literacy teaching tool in early childhood. International Journal of Education in Mathematics, Science and Technology, 1(1), 16-24.

Bhattacherjee, A., \& Hikmet, N. (2007). Physicians' resistance toward healthcare information technology: A theoretical model and empirical test. European Journal of Information Systems, 16(6), 725-737.

Bourgonjon, J., De Grove, F., De Smet, C., Van Looy, J., Soetaert, R., \& Valcke, M. (2013). Acceptance of gamebased learning by secondary school teachers. Computers \& Education, 67(0), 21-35. doi:http://dx.doi.org/10.1016/j.compedu.2013.02.010

Chen, F, Looi, C., \& Chen, W. (2009). Integrating technology in the classroom: A visual conceptualization of teachers' knowledge, goals and beliefs. Journal of Computer Assisted Learning, 25(5), 470-488. doi:10.1111/j.1365-2729.2009.00323.x

Chen, H., \& Tseng, H. (2012). Factors that influence acceptance of web-based e-learning systems for the inservice education of junior high school teachers in taiwan. Evaluation and Program Planning, 35(3), 398406. doi:http://dx.doi.org/10.1016/j.evalprogplan.2011.11.007

Chen, L., Gillenson, M. L., \& Sherrell, D. L. (2002). Enticing online consumers: An extended technology acceptance perspective. Information \& Management, 39(8), 705-719. doi:http://dx.doi.org/10.1016/S03787206(01)00127-6

Chen, Y., Lin, Y., Yeh, R. C., \& Lou, S. (2013). Examining factors affecting college students' intention to use web-based instruction systems: Towards an integrated model. Turkish Online Journal of Educational Technology, 12(2), 111-121.

Compeau, D. R., \& Higgins, C. A. (1995). Computer self-efficacy: Development of a measure and initial test. MIS Quarterly, 19(2), 189-211. doi:10.2307/249688

Conde González, M. Á, García Peñalvo, F. J., Alier, M., \& Piguillem, J. (2013). The implementation, deployment and evaluation of a mobile personal learning environment. Journal of Universal Computer Science, 19(7), January 18, 2014-http://www.jucs.org/jucs 19 7/the implementation deployment and.

Conde, M. Á, García-Peñalvo, F. J., Rodríguez-Conde, M. J., Alier, M., Casany, M. J., \& Piguillem, J. (2012). An evolving learning management system for new educational environments using 2.0 tools. Interactive Learning Environments, , 1-17. doi:10.1080/10494820.2012.745433

Dabbagh, N., \& Kitsantas, A. (2012). Personal learning environments, social media, and self-regulated learning: A natural formula for connecting formal and informal learning. The Internet and Higher Education, 15(1), 38. doi:http://dx.doi.org/10.1016/j.iheduc.2011.06.002

Davis, F. D. (1986). A technology acceptance model for empirically testing new end-user information systems: Theory and results. Massachusetts Institute of Technology, Massachussets.

Davis, F. D. (1989). Perceived usefulness, perceived ease of use, and user acceptance of information technology. MIS Quarterly, 13(3), 319-340.

Davis, F. D., Bagozzi, R. P., \& Warshaw, P. R. (1992). Extrinsic and intrinsic motivation to use computers in the Workplace1. Journal of Applied Social Psychology, 22(14), 1111-1132. doi:10.1111/j.15591816.1992.tb00945.x 
Sánchez Prieto, J. C., Olmos Migueláñez, S., \& García-Peñalvo, F. J. (2016). Informal Tools in Formal Contexts: Development of a Model to Assess the Acceptance of Mobile Technologies among Teachers. Computers in Human Behavior, 55A, 519-528.

De Smet, C., Bourgonjon, J., De Wever, B., Schellens, T., \& Valcke, M. (2012). Researching instructional use and the technology acceptation of learning management systems by secondary school teachers. Computers $\&$ Education, 58(2), 688-696. doi:http://dx.doi.org/10.1016/j.compedu.2011.09.013

Deshpande, Y., Bhattacharya, S., \& Yammiyavar, P. (2012). A behavioral approach to modeling indian children's ability of adopting to e-learning environment. Intelligent Human Computer Interaction (IHCI), 2012 th International Conference on, 1-7. doi:10.1109/IHCI.2012.6481776

Echeng, R., Usoro, A., \& Majewski, G. (2013). Acceptance of web 2.0 in learning in higher education: An empirical study of a scottish university. International Journal of Advanced Computer Science and Applications, 4(10), 30-38.

Escobar-Rodríguez, T., \& Bartual-Sopena, L. (2014). Impact of cultural factors on attitude toward using ERP systems in public hospitals. Revista De Contabilidad, In press doi:doi:10.1016/j.rcsar.2014.04.002

Fishbein, M., \& Ajzen, I. (1975). Belief, attitude, intention, and behavior: An introduction to theory and research. Reading, Massachusets: Addison-Wesley Pub. Co.

Fundación Telefónica. (2014). La sociedad de la información en españa 2014. Retrieved from http://www.fundacion.telefonica.com/es/arte cultura/publicaciones/sie/sie2013.htm

Gao, Y. (2005). Applying the technology acceptance model to educational hypermedia: A field study. Journal of Educational Multimedia and Hypermedia, 14(3), 237-247.

Gefen, D., Karahanna, E., \& Straub, D. W. (2003). Trust and TAM in online shopping: An integrated model. MIS Quarterly, 27(1), 51-90.

Guo, X., Sun, Y., Wang, N., Peng, Z., \& Yan, Z. (2013). The dark side of elderly acceptance of preventive mobile health services in china. Electronic Markets, 23(1), 49-61. doi:10.1007/s12525-012-0112-4

Heijden, H. v. d. (2000). E-tam : A revision of the technology acceptance model to explain website revisits.VU University Amsterdam, Faculty of Economics, Business Administration and Econometrics.

Hernández García, Á. (2008). Desarrollo de un modelo unificado de adopción del comercio electrónico entre empresas y consumidores finales. aplicación al mercado español . E.T.S.I. Telecomunicación (UPM), Madrid.

Hernández-Ramos, J. P., Martínez-Abad, F., García Peñalvo, F. J., Esperanza Herrera García, M., \& RodríguezConde, M. J. (2014). Teachers' attitude regarding the use of ICT. A factor reliability and validity study. Computers in Human Behavior, 31(0), 509-516. doi:http://dx.doi.org/10.1016/j.chb.2013.04.039

Hesser, T. L., \& Schwartz, P. M. (2013). iPads in the science laboratory: Experience in designing and implementing a paperless chemistry laboratory course. Journal of STEM Education: Innovations \& Research, 14(2), 5-9.

Holden, H., \& Rada, R. (2011). Understanding the influence of perceived usability and technology self-efficacy on teachers' technology acceptance. Journal of Research on Technology in Education, 43(4), 343-367.

Hsu, C., \& Lu, H. (2004). Why do people play on-line games? an extended TAM with social influences and flow experience. Inf.Manage., 41(7), 853-868. doi:10.1016/j.im.2003.08.014

Hu, P. J., Clark, T. H. K., \& Ma, W. W. (2003). Examining technology acceptance by school teachers: A longitudinal study. Information \& Management, 41(2), 227-241. doi:http://dx.doi.org/10.1016/S03787206(03)00050-8

Huffman, W. H., \& Huffman, A. H. (2012). Beyond basic study skills: The use of technology for success in college. Computers in Human Behavior, 28(2), 583-590. 
Sánchez Prieto, J. C., Olmos Migueláñez, S., \& García-Peñalvo, F. J. (2016). Informal Tools in Formal Contexts: Development of a Model to Assess the Acceptance of Mobile Technologies among Teachers. Computers in Human Behavior, 55A, 519-528.

Hung, M., \& Jen, W. (2012). The adoption of mobile health management services: An empirical study. Journal of Medical Systems, 36(3), 1381-1388.

Hutchison, A., Beschorner, B., \& Schmidt-Crawford, D. (2012). Exploring the use of the iPad for literacy learning. The Reading Teacher, 66(1), 15-23. doi:10.1002/TRTR.01090

Jou, M., \& Wang, J. (2012). Observations of achievement and motivation in using cloud computing driven CAD: Comparison of college students with high school and vocational high school backgrounds. Computers in Human Behavior, 29(2), 364-369. doi:http://dx.doi.org/10.1016/j.chb.2012.08.001

Karahanna, E., Agarwal, R., \& Angst, C. M. (2006). Reconceptualizing compatibility beliefs in technology acceptance research . MIS Quarterly, 30(4), 781-804.

King, W. R., \& He, J. (2006). A meta-analysis of the technology acceptance model. Information \& Management, 43(6), 740-755. doi:http://dx.doi.org/10.1016/j.im.2006.05.003

Kiraz, E., \& Ozdemir, D. (2006). The relationship between educational ideologies and technology acceptance in pre-service teachers. Journal of Educational Technology \& Society, 9(2), 152-165.

Koutromanos, G., Styliaras, G., \& Christodoulou, S. (2014). Student and in-service teachers' acceptance of spatial hypermedia in their teaching: The case of HyperSea. Education and Information Technologies, , 1-20. doi:10.1007/s10639-013-9302-8

Kuo, K., Liu, C., \& Ma, C. (2013). An investigation of the effect of nurses' technology readiness on the acceptance of mobile electronic medical record systems. BMC Medical Informatics and Decision Making, $13(1)$

Lee, M. K. O., Cheung, C. M. K., \& Chen, Z. (2005) Acceptance of internet-based learning medium: The role of extrinsic and intrinsic motivation. Information \& Management, 42(8), 1095-1104. doi:http://dx.doi.org/10.1016/j.im.2003.10.007

Lee, Y., Hsieh, Y., \& Hsu, C. (2011). Adding innovation diffusion theory to the technology acceptance model: Supporting employees' intentions to use E-learning systems. Journal of Educational Technology \& Society, 14(4), 124-137.

Legris, P., Ingham, J., \& Collerette, P. (2003). Why do people use information technology? A critical review of the technology acceptance model. Information \& Management, 40(3), 191-204. doi:http://dx.doi.org/10.1016/S0378-7206(01)00143-4

Liaw, S., Huang, H., \& Chen, G. (2007). Surveying instructor and learner attitudes toward e-learning. Computers \& Education, 49(4), 1066-1080. doi:http://dx.doi.org/10.1016/j.compedu.2006.01.001

Marangunié, N., \& Granié, A. (2014). Technology acceptance model: A literature review from 1986 to 2013. Universal Access in the Information Society, 14(1), 1-15. doi:10.1007/s10209-014-0348-1

Martínez Abad, F. (2013). Evaluación y formación en competencias informacionales en la educación secundaria obligatoria. Universidad de Salamanca. Salamanca, Spain.

Mills, L. A., Knezek, G., \& Khaddage, F. (2014). Information seeking, information sharing, and going mobile: Three bridges to informal learning. Computers in Human Behavior, 32(0), 324-334. doi:http://dx.doi.org/10.1016/j.chb.2013.08.008

Navarro, I., Galindo, A., \& Fonseca, D. (2013). Augmented reality uses in educational research projects: The falcones project, a case study applying technology in the humanities framework at high school level. Proceedings of the First International Conference on Technological Ecosystem for Enhancing Multiculturality, Salamanca, Spain. 411-415. doi:10.1145/2536536.2536599 
Sánchez Prieto, J. C., Olmos Migueláñez, S., \& García-Peñalvo, F. J. (2016). Informal Tools in Formal Contexts: Development of a Model to Assess the Acceptance of Mobile Technologies among Teachers. Computers in Human Behavior, 55A, 519-528.

Ong, C., \& Lai, J. (2006). Gender differences in perceptions and relationships among dominants of e-learning acceptance. Computers in Human Behavior, 22(5), 816-829.

Park, N., Lee, K. M., \& Cheong, P. H. (2007). University instructors' acceptance of electronic courseware: An application of the technology acceptance model. Journal of Computer-Mediated Communication, 13(1), 163186.

Persico, D., Manca, S., \& Pozzi, F. (2014). Adapting the technology acceptance model to evaluate the innovative potential of e-learning systems. Computers in Human Behavior, 30, 614-622.

Pynoo, B., \& van Braak, J. (2014). Predicting teachers' generative and receptive use of an educational portal by intention, attitude and self-reported use. Computers in Human Behavior, 34(0), 315-322. doi:http://dx.doi.org/10.1016/j.chb.2013.12.024

Ramayah, T. (2010). The role of voluntariness in distance education students' usage of a course website. Turkish Online Journal of Educational Technology, 9(3), 96-105.

Roca, J. C., \& Gagné, M. (2008a). Understanding e-learning continuance intention in the workplace: A selfdetermination theory perspective. Computers in Human Behavior, 24(4), 1585-1604. doi:http://dx.doi.org/10.1016/j.chb.2007.06.001

Roca, J. C., \& Gagné, M. (2008b). Understanding e-learning continuance intention in the workplace: A selfdetermination theory perspective. Computers in Human Behavior, 24(4), 1585-1604 doi:http://dx.doi.org/10.1016/j.chb.2007.06.001

Rogers, E. M. (1995). Diffusion of innovations (4th ed.). New York: Free Press.

Rossing, J. P., Miller, W. M., Cecil, A. K., \& Stamper, S. E, (2012). iLearning: The future of higher education? student perceptions on learning with mobile tablets. Journal of Scholarship of Teaching and Learning, 12(2), $1-26$.

Saadé, R., \& Bahli, B. (2005). The impact of cognitive absorption on perceived usefulness and perceived ease of use in on-line learning: An extension of the technology acceptance model. Information \& Management, 42(2), 317-327. doi:http://dx.doi.org/10.1016/j.im.2003.12.013

Sánchez Prieto, J. C., Olmos Migueláñez, S., García Peñalvo, F. J., \& Torrecilla Sánchez, E. M. (2014). Las tabletas digitales en educación formal: Características principales y posibilidades pedagógicas. IV Congreso Internacional De Competenciás Básicas: Competencia Digital Y Tratamiento De La Información. Aprender En El Siglo XXI, Ciudad Real, España.

Sánchez, R. A., \& Hueros, A. D. (2010). Motivational factors that influence the acceptance of moodle using TAM. Computers in Human Behavior, 26(6), 1632-1640. doi:http://dx.doi.org/10.1016/j.chb.2010.06.011

Schepers, J., \& Wetzels, M. (2007). A meta-analysis of the technology acceptance model: Investigating subjective norm and moderation effects. Information \& Management, 44(1), 90-103. doi:http://dx.doi.org/10.1016/j.im.2006.10.007

Sharples, M., Amedillo Sanchez, I., Milrad, M., \& Vavoula, G. (2009). Mobile learning: Small devices, big issues. In N. Balacheff, S. Ludvigsen, T. d. Jong \& S. Barnes (Eds.), Technology enhanced learning: Principles and products (pp. 233-249). Heidelberg: Springer.

Stantchev, V., Colomo-Palacios, R., Soto-Acosta, P., \& Misra, S. (2014). Learning management systems and cloud file hosting services: A study on students' acceptance. Computers in Human Behavior, 31(1), 612-619.

Teo, T. (2012a). Proposing a model to explain teachers' intention to use technology: Identifying constructs and formulating hypotheses. International Journal of Information and Communication Technology Education, $8(3), 22-27$. 
Sánchez Prieto, J. C., Olmos Migueláñez, S., \& García-Peñalvo, F. J. (2016). Informal Tools in Formal Contexts: Development of a Model to Assess the Acceptance of Mobile Technologies among Teachers. Computers in Human Behavior, 55A, 519-528.

Teo, T. (2009). Modelling technology acceptance in education: A study of pre-service teachers. Computers \& Education, 52(2), 302-312. doi:http://dx.doi.org/10.1016/j.compedu.2008.08.006

Teo, T. (2010). A path analysis of pre-service teachers' attitudes to computer use: Applying and extending the technology acceptance model in an educational context. Interactive Learning Environments, 18(1), 65-79. doi:10.1080/10494820802231327

Teo, T. (2011). Factors influencing teachers' intention to use technology: Model development and test. Computers \& Education, 57(4), 2432-2440. doi:http://dx.doi.org/10.1016/j.compedu.2011.06.008

Teo, T. (2012b). Examining the intention to use technology among pre-service teachers: An integration of the technology acceptance model and theory of planned behavior. Interactive Learning Environments, 20(1), 318. doi:10.1080/10494821003714632

Teo, T., \& Noyes, J. (2011). An assessment of the influence of perceived enjoyment and attitude on the intention to use technology among pre-service teachers: A structural equation modeling approach. Computers \& Education, 57(2), 1645-1653. doi:http://dx.doi.org/10.1016/j.compedu.2011.03.002

Traxler, J. (2009). Current state of mobile learning. In M. Ally (Ed.), Mobile learning: Transforming the delivery of education and training (pp. 9-25). Edmonton: AU Press.

van Dinther, M., Dochy, F., Segers, M., \& Braeken, J. (2013). The construct validity and predictive validity of a self-efficacy measure for student teachers in competence-based education. Studies in Educational Evaluation, 39(3), 169-179. doi:http://dx.doi.org/10.1016/j.stueduc.2013.05.001

Morales Vallejo, P., Urosa Sanz, B., \& Blanco Blanco, A. (2003). Construcción de escalas de actitudes tipo likert. Madrid (Spain): La Muralla.

Venkatesh, V., \& Davis, F. D. (2000). A theoretical extension of the technology acceptance model: Four longitudinal field studies. Management Science, 46(2), 186-204.

Venkatesh, V., \& Bala, H. (2008). Technology acceptance model 3 and a research agenda on interventions. Decision Sciences, 39(2), 273-315. doi:10.1111/j.1540-5915.2008.00192.x

Venkatesh, V., Morris, M. G., Gordon B. Davis, \& Davis, F. D. (2003). User acceptance of information technology: Toward a unified view. MIS Quarterly, 27(3), 425-478.

Wishart, J., \& Triggs, P. (2010). MuseumScouts: Exploring how schools, museums and interactive technologies can work together to Support learning. Computers \& Education, 54(3), 669-678. doi:http://dx.doi.org/10.1016/j.compedu.2009.08.034

Wu, C., \& Liu, C. (2013). Acceptance of ICT-mediated teaching/learning systems for elementary school teachers: Moderating effect of cognitive styles. Education and Information Technologies, 1-21. doi:10.1007/s10639013-9290-8

Wu, I., \& Chen, J. (2005). An extension of trust and TAM model with TPB in the initial adoption of on-line tax: An empirical study. International Journal of Human-Computer Studies, 62(6), 784-808. doi:http://dx.doi.org/10.1016/j.ijhcs.2005.03.003

Yadegaridehkordi, E., Iahad, N. A., \& Baloch, H. Z. (2013). Success factors influencing the adoption of Mlearning. International Journal of Continuing Engineering Education and Life-Long Learning, 23(2), 167178.

Yamakawa, P., Delgado, C., Díaz, E., Garayar, E., \& Laguna, H. (2013). Factors influencing the use of mobile technologies in a university environment: A case from latin america. International Journal of Information and Communication Technology Education, 9(2), 24-38. 
Sánchez Prieto, J. C., Olmos Migueláñez, S., \& García-Peñalvo, F. J. (2016). Informal Tools in Formal Contexts: Development of a Model to Assess the Acceptance of Mobile Technologies among Teachers. Computers in Human Behavior, 55A, 519-528.

Yang, Z., Cai, S., Zhou, Z., \& Zhou, N. (2005). Development and validation of an instrument to measure user perceived service quality of information presenting web portals. Information \& Management, 42(4), 575589. doi:http://dx.doi.org/10.1016/j.im.2004.03.001

Yu, K., Lin, K., Han, F., \& Hsu, I. (2012). A model of junior high school studentsâ€ $€^{\mathrm{TM}}$ attitudes toward technology. International Journal of Technology and Design Education, 22(4), 423-436. doi:10.1007/s10798-011-9154-8

Yuen, A. H. K., \& Ma, W. W. K. (2008). Exploring teacher acceptance of e-learning technology. Asia-Pacific Journal of Teacher Education, 36(3), 229-243.

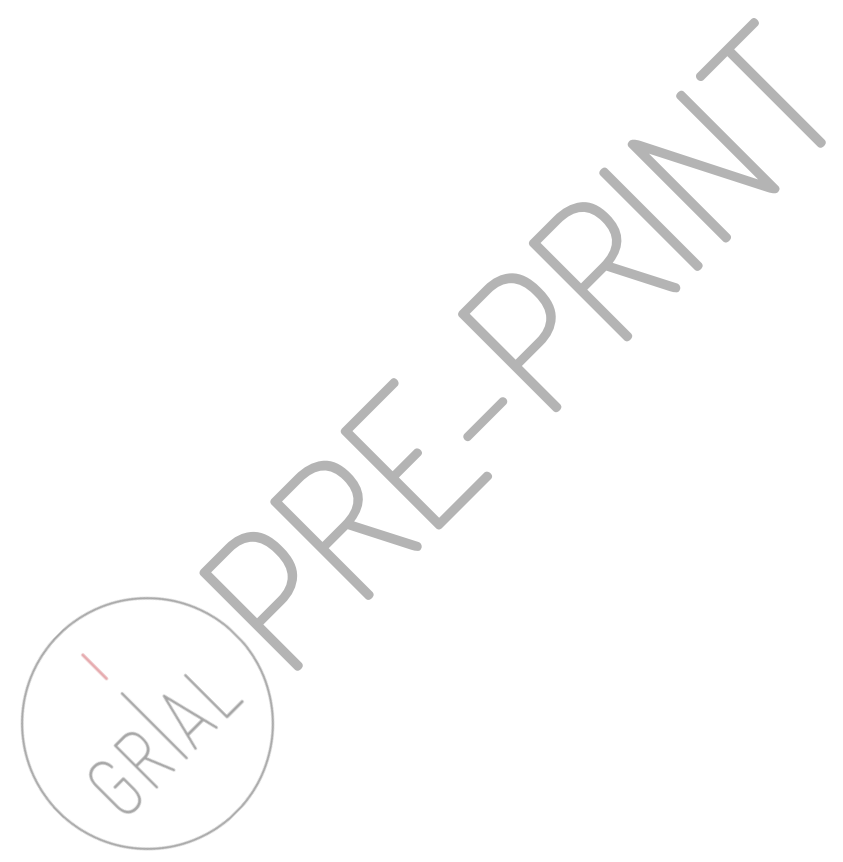

